\title{
ANALISA SIFAT FISIKOKIMIA TANIN KULIT AKASIA MANGIUM UNTUK BAHAN BAKU PEREKAT
}

\author{
Eldha Sampepana ${ }^{1)}$ dan Enih Rosamah ${ }^{2)}$, \\ 7) Balai Riset dan Standardisasi Samarinda ${ }^{2)}$ Fakultas Kehutanan Universitas Mulawarman
}

\begin{abstract}
Tannin is a derivative from organic compound from glycosides found in various plants, the most important commercial condensed tannin obtained from gymnosperms species for example Acacia mangium. Tannin is one of the adhesive materials that can have a dimensional stability of wood. Tannin contains flavonoid compounds that have hydroxyl groups that are reactive to condense against other materials as a cross-link agent, like formaldehyde, which may increase the number of polymer units of tannins, thus increasing the bonding strength of tannin based adhesives. Based on the results of physicochemical analysis of extracts (tannins) from the bark of A. mangium as a raw material for adhesives, it can be concluded that the A. mangium tannin had a higher reactivity toward formaldehyde of $96 \%$, reactivity of tannin toward hexamethylene tetramine of $46.18 \%$, tannins toward ethylene glycol of $3.07 \%$ and tannins toward dimethylol urea of $183.59 \%$. Meanwhile, the value of reactive polyphenol content determined by UV-Method showed in tannin with formaldehyde of $97.65 \%$. tannins with hexamethylene tetramine of $46 \%$, tannins with ethylene glycol of $2 \%$, and tannins with dimethylolurea of $56.26 \%$. The results of gelation time (gel time) measurements fullifiled the requirements of JIS K 68331980 by the treatment of hexamethylenen tetramine for variable II and III, and the treatment of ethylene giycol (variable VI). The viscosity values by the treatment of hexamethylenen tetramine (variable $I I, I I I$, and $\mathrm{IV}$ ), for ethylene glycol (variable II - VI) met the requirement conditions by JIS K $6833-1980$.
\end{abstract}

Keywords: tannin, hexamethylene tetramine, dimethylol urea, ethylene glycol

\section{PENDAHULUAN}

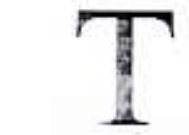

anin merupakan komponen zat organik derivat /turunan polimer glikosida yang terdapat dalam bermacam-macam tumbuhan, terutama tumbuhan berkeping dua (dikotil) yang terdiri dari campuran senyawa polifenol kompleks dibangun dari unsur karbon (C), Hidrogen $(\mathrm{H})$, dan oksigen $(\mathrm{O})$ yang membentuk molekul dengan bobot molekul lebih besar dari 2000. Salah satu senyawa kimia atau monomer tanin yang dirangkaikan adalah digallic acid dan D-glukosa dan tergabung dengan karbohidrat rendah membentuk tanin formaldehida yang dapat digunakan sebagai bahan perekat kayu lapis eksterior maupun interior (Subiyakto, 2008).

Tanin juga merupakan senyawa flavonoid yang mempunyai banyak gugus fenoksi yang reaktif dengan bahan lain yang berfungsi sebagai cross link agent seperti formaldehida, bila bercampur dapat meningkatkan jumlah unit polimer tanin sehingga meningkatkan daya rekat perekat tanin. 
Tanin ini diperoleh dari limbah kulit kayu Acacia mangium yang cukup besar potensinya di Kalimantan Timur. Bahan ini berasal dari limbah indutri MDF yang ada di Senoni Kabupaten Kutai Kartanegara. Data dari industri ini menunjukkan bahwa limbah kulit kayu akasia yang dihasilkan sebesar 1500 ton/bulan (Anonim, 2006). Limbah kulit kayu akasia mangium selama ini belum dimanfaatkan, hanya terbuang begitu saja. Hal ini juga dinyatakan oleh Subiyakto (2008), bahwa limbah kulit kayu akasia sangat berlimpah dan belum termanfaatkan. Berdasarkan hasil ekstraksi, kulit kayu akasia

\section{BAHAN DAN METODE}

\section{Bahan dan Peralatan}

Bahan yang digunakan antara lain kulit kayu Akasia, $\mathrm{NaCl}, \mathrm{HCl}$, asam asetat, etil asetat, TLC sellulosa, toulenan, kloroform, amoniak, metanol, aseton, etanol, butanol, $\mathrm{H}_{2} \mathrm{SO}_{4}$, air, kain saring, resin MF (melamin formaldehida), aquades, kertas saring, formaldehida $37 \%$, amonium sulfat, dimethylol urea, heksamethylene tetramine, ethylene glycol, masker, kertas $\mathrm{pH}$, acethylene acetate, natrium hidroksida, natrium

\section{Metoda}

\section{Proses Ekstraksi Kulit Kayu Akasia Mangium}

Sebeluin melakukan ekstraksi tanin dari kulit kayu akasia, terlebih dahulu dilakukan penyortiran kulit kayu dan pembersihan dari kotoran. Selanjutnya kulit kayu dipotong-potong kecil dengan ukuran $0,5 \times 0,5 \mathrm{~cm}$, kemudian dikeringkan. Setelah kering lalu dibuat serbuk dengan ukuran 60 mesh.

Serbuk kulit kayu akasia diekstraksi dengan air panas di dalam digester, dengan perbandingan antara kulit kayu akasia dan air 1 : 5 berdasarkan berat kulit kering tanur. Ekstraksi dilakukan pada suhu $100^{\circ} \mathrm{C}$ selama 3 jam, dengan menjaga mengandung kadar ekstraktif sekitar 40 persen, dimana ekstrak yang diperoleh tersebut kaya akan kandungan polifenol alam, yaitu tanin. Tanin ini, berdasarkan hasil dari beberapa penelitian, sangat berguna dalam proses perekatan.

Melihat begitu banyak potensi limbah kulit kayu akasia mangium, maka dipandang perlu untuk melakukan suatu penelitian. Adapun tujuan dari penelitian ini adalah untuk mengetahui sifat fisika kimia tanin kulit kayu akasia mangium sebagai bahan baku

perekat.

karbonat, dan bahan penolong lainnya.

Sedangkan alat yang digunakan antara lain digester, TLC small drop, vacuum evaporator, oven, neraca analitik, alat refluks, $\mathrm{pH}$ meter, mesin penyaring, mesin serbuk, spektrofotometer, water Bath, thermometer, corong pemisah, erienmayer, pipet tetes, beaker glass, hot plate, pengaduk, thermometer. labu ukur, gelas ukur, dan alat lainnya.

perbandingan kulit dan air 1:5 selama proses ekstraksi. Setelah diekstraksi kemudian disaring dengan kain katun, dan kemudian disaring dengan kertas saring dan dengan menggunakan vakum. Hasil saringan tersebut dikeringkan dalam oven dan evaporator dengan suhu $60^{\circ} \mathrm{C}$. (Roffael dan Ayla, 1982 dalam Rosamah, 1997).

\section{Rancangan Percobaan}

Pembuatan formulasi perekat berbasis tanin dengan melakukan pencampuran melamin formaldehida dengan ekstrak tanin dengan berbagai perlakuan. Formulasi perekat yang digunakan berdasarkan pada berat kering tanur serat, kadar air serat, 
volume papan dan solid content masing-masing bahan yang akan dipakai dalam perekatan. Perekat ini dibuat dari campuran melamin formaldehida, hexamintetramin dan ekstrak tanin, dengan formulasi perekat seperti terlihat pada Tabel 1.

Tabel 1. Perlakuan Perekat Antara Ekstrak Tanin Dengan Hexamintetramin Dan Melamin Formaldehide

\begin{tabular}{c|c|c|c}
\hline \multirow{2}{*}{ Variabel } & \multicolumn{3}{|c}{ Bedasarkan Berat serat (kering udara) } \\
\cline { 2 - 4 } & Ekstrak Tanin & MF & Hexamin tetramin \\
\hline I & $20 \%$ & $80 \%$ & $0 \%$ \\
\hline II & $20 \%$ & $70 \%$ & $10 \%$ \\
\hline III & $20 \%$ & $60 \%$ & $20 \%$ \\
\hline IV & $20 \%$ & $50 \%$ & $30 \%$ \\
\hline V & $20 \%$ & $40 \%$ & $40 \%$ \\
\hline VI & $20 \%$ & $0 \%$ & $80 \%$ \\
\hline
\end{tabular}

Sedangkan perlakuan perekat dengan ethylen glycol, dimethylol urea dengan MF dan ekstrak tanin sama dengan formulasi pada tabel diatas, tetapi dengan mengganti jenis bahan kimia hexamethylene tetramine dengan dimethylolurea atau ethylene glycol. Pembuatan perekat dengan perlakuan seperti pada table 1, masing-masing perlakuan dilakukan sebanyak 3 kali ulangan.

\section{Parameter Yang Diuji}

Parameter yang diuji adalah pengujian reaktivitas ekstrak (tanin) akasia mangium terhadap bahan pengikat (cross-linking agent) dengan penentuan kadar polifenol yang dinyatakan dengan bilangan stiasny dan penentuan kadar polifenol aktif dengan uv metode, derajat keasaman $(\mathrm{pH})$ dan kapasitas buffer, waktu gelatinasi, dan viskositas (Rosamah, 2003).

\section{HASIL DAN PEMBAHASAN}

\section{Penentuan Bilangan Stiasny dan UV Metode}

Hasil penelitian sebelumnya menunjukkan bahwa ekstrak kulit akasia mangium sangat reaktif terhadap formaldehida, dimana dalam hal ini formaldehida berfungsi sebagai cross-lingking agent. Penelitian ini mencoba melihat reaktivitas ekstrak kulit akasia mangium dengan menggunakan bahan cross-linking agent yang lain selain formaldehida. Bahan yang digunakan sebagai crosslinking agent pengganti adalah hexamethylene tetramine, ethylene glycol dan dimethylolurea (Rosamah, 2003) Kereaktifan ekstrak kulit kayu akasia mangium terhadap bahan pengikat (cross- linking agent selain formaldehid) hexamethylene tetramine, ethylene giycol dan dimethylolurea dapat dilihat dari nilai bilangan stiasny dan UV metode. Hal ini dapat dilihat pada Tabel 2. 
Tabel 2. Penentuan Nilai Bilangan Stiasny Dan UV Metode Bahan Perekat

\begin{tabular}{l|c|c}
\hline \multicolumn{1}{c|}{ Uraian } & Bilangan Stiasny (\%) & UV Metode (\%) \\
\hline Tanin terhadap formaldehida & 96 & 97,65 \\
\hline $\begin{array}{l}\text { Tanin terhadap hexamethylene } \\
\text { tetramine }\end{array}$ & 46,18 & 56,26 \\
\hline tanin terhadap ethylene glycol & 3,07 & 2 \\
\hline tanin terhadap dimethylolurea & 183,59 & 56,26 \\
\hline
\end{tabular}

Dari hasil penelitian pada tabel 2 terlihat bahwa reaktivitas tanin terhadap hexamethylene tetramine, ethylene glycol dan dimethylolurea berkurang dibandingkan dengan reaktifitas tanin terhadap formaldehida. Hal ini disebabkan bahwa dari beberapa bahan cross-linking agent yang digunakan, hanya formaldehida yang paling sesuai dengan karakteristik molekul tanin. Disamping itu masih banyak komponen kimia non tanin seperti gula, pati, pektin, selulosa dan zat pengotor lainnya yang berasal dari kulit kayu.

Senyawa tanin juga dikenal mempunyai bobot molekul tinggi yang tidak dapat bereaksi pada proses pembentukan resin tanin dengan hexamethylene tetramine dan ethylene glycol sehingga menghasilkan bobot ekstrak tak larut rendah. Sedangkan untuk pembentukan resin tanindimethylolurea dan resin taninformaldehida tinggi karena menghasilkan bobot ekstrak tak larut tinggi. Makin tinggi bilangan stiasny maka kereaktifan tanin tersebut terhadap formaldehida semakin tinggi pula (semakin reaktif). Selain itu juga nilai bilangan stiasny dapat memperkirakan total flavonoid dalam ekstrak ketika direaksikan dengan formaldehida dalam perekat (Yazaki et.al,1998).

Nilai bilangan stiasny yang cukup tinggi pada tanin menunjukkan kereaktifan tanin terhadap formaldehida tinggi. Menurut Rosamah, 1997 bahwa ada beberapa faktor yang mempengaruhi reaktivitas tanin antara lain spesies, umur kayu, lokasi tempat tumbuh, iklim, musim, saat kulit kayu tersebut dipanen, proses ekstraksi dan usia dari ekstrak. Pada daerah subur. pembentukan zat ekstraktif seperti karbohidrat, kelompok gula sederhana dan komponen lainnya dapat berlangsung dengan baik dibanding ditempat yang rendah kesuburannya. $\mathrm{Hal}$ ini sesuai dengan pendapat Hillis, 1976 dalam Estira, 1998 dikutip oleh Suhendry, 2006 bahwa kandungan zat ekstraktif dapat dipengaruhi oleh proses fotosintesis, sedangkan proses fotosintesis dipengaruhi oleh intesitas cahaya, temperatur, kadar air, kesuburan tanah dan aktivitas metabolisme dalam pertumbuhan.

Berdasarkan hasil uji uv-metode, reaktifitas tanin terhadap hexamethylene tetramine, ethylene glycol rendah dan reaktifitas tanin terhadap dimethylolurea sedang sedangkan untuk reaktifitas tanin terhadap formaldehida tinggi. Hal ini disebabkan komponen bahan crosslinking agent tersebut berbeda satu sama lain, dan formaldehida yang paling cocok dan paling mudah bereaksi dengan tanin. Disamping itu karena zat ekstraktif dalam tanin tersebut mengandung senyawa dari kelompok non tanin yang akan menggangu proses reaksi dan menurunkan reaktivitas antara tanin dengan hexamethylene tetramine, ethylene glycol dan dimethylolurea.

\section{Penentuan Waktu Gelatinasi}

Waktu gelatinasi adalah waktu yang diperlukan oleh campuran perekat untuk membentuk gel (mengeras) setelah dipanaskan beberapa lama di dalam water bath dengan suhu $90^{\circ} \mathrm{C}$. Selain itu juga menurut Rowell, 2005 bahwa waktu gelatinasi menunjukan waktu yang dibutuhkan perekat untuk 
mengental atau menjadi gel, sehingga tidak dapat ditambahkan lagi dengan bahan lain dan siap untuk direkatkan.

Untuk waktu gelatinasi campuran perekat tanin dengan hexamethylene tetramine, perekat tanin dengan dimethylolurea dan perekat tanin dengan ethylene glycol dapat dilihat pada Tabel

Tabel 3. Penentuan Nilai Waktu Gelatinasi Perekat

\begin{tabular}{c|c|c|c}
\hline \multirow{2}{*}{ Variabel } & \multicolumn{3}{|c}{ Waktu gelatinasi (menit) } \\
\cline { 2 - 4 } & $\mathrm{H}$ & $\mathrm{D}$ & $\mathrm{E}$ \\
\hline I & 6 & 6 & 6 \\
\hline II & 54 & 11 & 8 \\
\hline III & 58 & 4 & 14 \\
\hline IV & 5 & - & 8 \\
\hline V & 8 & - & 11 \\
\hline VI & 12 & - & 185 \\
\hline JIS K 6833-1980 & \multicolumn{3}{|c}{} \\
\hline
\end{tabular}

Keterangan: - : Tidak terdeteksi, $H$ : Hexamethylene tetramine; D: Demehtylol urea; $E$ : Ethylene glycol

Pada tabel 3 menunjukkan bahwa waktu gelatinasi perekat tertinggi untuk hexamethylene tetramine pada $\mathrm{H} .60$ yaitu 58 menit, dan terendah pada $\mathrm{H} .80$ yaitu 6 menit, dan waktu gelatinasi untuk dimethylolurea adalah teringgi pada D.70 yaitu 11 menit dan terendah pada $D .60$ yaitu 4 menit. Sedangkan waktu gelatinasi untuk ethylene glycol tertinggi pada $E .0$ yaitu 3 jam 5 menit (185 menit) dan terendah pada E.80 yaitu 6 menit. $\mathrm{Hal}$ ini menunjukan bahwa waktu gelatinasi dipengaruhi oleh massa bahan, kecepatan reaksi, pengadukan bahan, dan sifat dari bahan tersebut. Hal ini dapat dilihat pada tabel diatas bahwa waktu gelatinasi dimethylol urea lebih cepat dibandingkan dengan hexamethylene tetramine dan ethylene glycol. Waktu gelatinasi yang tercepat pada D.60 dan terlambat pada E.0.

$\mathrm{Hal}$ ini dipertegas oleh Sujanto, 1995 bahwa meningkatnya viskositas akan menyebabkan penggumpalan cepat terjadi, sehingga mengakibatkan perekat tersebut segera mengeras sehingga waktu gelatinasinya semakin pendek atau cepat. Selain itu menurut Santoso, 1995 dalam Parastuti, 2002 bahwa semakin tinggi konsentrasi bahan yang ditambahkan dalam tanin, waktu gelatinasi akan semakin pendek (cepat) karena akan menaikkan $\mathrm{pH}$ tanin, mengakibatkan kekentalan perekat semakin meningkat. Waktu lama pada perekatan tidak diinginkan karena berpengaruh pada proses pemberian tekanan dalam proses perekatan. Sedangkan waktu tercepat pada saat perekatan terjadi karena tanin bersifat higroskopis dimana pada ekstrak tanin juga terdapat bahan non tanin seperti gula, pati, pektin, dan lainlain sehingga mudah menyerap air.

$$
\text { Semakin cepat waktu }
$$
gelatinasinya berarti semakin pendek pot life. Hal ini dinyatakan oleh Santoso, 1995 dalam Parastuti, 2002 bahwa waktu gelatinasi dapat digunakan untuk menduga seberapa lama umur dari suatu perekat (pot life).

Dari waktu gelatinasi yang diperoleh memenuhi syarat yang ditetapkan oleh JIS K 6833-1980 adalah perlakuan untuk hexamethylenen tetramine yaitu : variabel II, III, untuk ethylene glycol yaitu variabel VI. Sedangkan untuk dimethylol urea tidak memenuhi syarat.

\section{Penentuan Viskositas}

Viscositas atau kekentalan merupakan salah satu sifat yang 
penting dalam perekatan. Kekentalan menunjukan kemampuan perekat untuk merngalir pada permukaan yang direkat. Nilai viskositas sangat berpengaruh terhadap mutu perekatan. Dari Hasil penenelitian menunjukkan bahwa nilai viskositas untuk hexamethylene tetramine, dimethylolurea dan ethylene glycol bervariasi untuk masing-masing perlakuan, seperti dapat dilihat pada Tabel 4.

Tabel 4. Penentuan Nilai Viskositas Perekat

\begin{tabular}{c|c|c|c}
\hline \multirow{2}{*}{ Variabel } & \multicolumn{3}{|c}{ Viskositas (dpa.s/poise) } \\
\cline { 2 - 4 } & $H$ & $D$ & $E$ \\
\hline I & 15 & 15 & 15 \\
\hline II & 6 & 20 & 10 \\
\hline III & 5 & 50 & 6 \\
\hline V & 3 & - & 5 \\
\hline VI & 0.65 & - & 4 \\
\hline JIS K 6833-1980 & 0.35 & - & 3 \\
\hline
\end{tabular}

Keterangan: $\quad-:$ Tidak terdeteksi, $H$ : Hexamethylene tetramine; $D:$ Demehtylol urea; E: Ethylene glycol, 1 poise $=1$ dpa.s

Nilai viskositas untuk perekat hexamethylene tetramine tertinggi pada H.80 dan terendah pada $\mathrm{H}, \mathrm{O}$. Begitu juga nilai viskositas untuk perekat ethylene glycol, nilai viskositas tertinggi pada E.80 dan terendah pada E.O. Sedangkan nilai viskositas untuk perekat dimethylolurea tertinggi pada D. 60 dan terendah pada D.80. Hal ini berati bahwa semakin banyak hexamethylene dan ethylene giycol ditambahkan pada masing-masing perlakuan semakin kecil nilai viskositasnya, semakin banyak dimethylolurea ditambahkan pada perlakuan perekat maka semakin tinggi nilai viskositasnya. Hal ini disebabkan bahwa perlakuan perekat dilakukan hanya sampai perlakuan D.60 karena sifat bahan dimethylolurea higroskopis dan mudah menyerap air dan mudah mengeras.

Menurut Sujanto, 1995 bahwa viskositas yang tinggi akan mengurangi pot life bahan perekat dan viskositas yang terendah akan menyebabkan perekat tidak tahan pada kelembaban. Selain itu juga semakin tinggi kekentalan, maka kemampuan untuk membasahi atau berpenetrasi kedalam void permukaan yang direkat akan semakin sulit. Namun, jika kekentalan terialu rendah, maka akan terjadi penetrasi perekat kedalam permukaan void yang direkat yang berlebihan dan menyebabkan miskinnya garis rekat yang terbentuk (Ruhedi, 1997).

Dari nilai viskositas yang diperoleh yang memenuhi syarat yang ditetapkan oleh JIS K 6833-1980 adalah perlakuan untuk hexamethylenen tetramine yaitu : variabel II, III, dan IV, untuk ethylene glycol yaitu variabel II s.d variabel VI. Sedangkan untuk dimethylol urea tidak memenuhi syarat.

\section{Penentuan $\mathrm{pH}$ dan Kapasitas Buffer}

Penentuan $\mathrm{pH}$ bertujuan untuk mengetahui sifat kadar keasaman atau basa dari suatu bahan atau perekat. Dari hasil penelitian menunjukkan bahwa tanin bersifat asam dan perekat dengan penambahan hexamethylene tetramine, dimethylolurea, dan ethylene glycol juga bersifat asam. Hasil selengkapnya dapat dilihat pada Tabel 5. 
Tabel 5. Penentuan Nilai pH dan Kapasitas Buffer

\begin{tabular}{|c|c|c|c|c|}
\hline Kode Sampel & Nilai pH Awal & $\begin{array}{l}\text { Nilai } \mathrm{pH} \\
\text { Akhir }\end{array}$ & $\begin{array}{c}\text { Nilai Kapasitas } \\
\text { Buffer (mmol } \\
\mathrm{NaOH} / 100 \mathrm{~g} \\
\text { Serat) }\end{array}$ & $\begin{array}{c}\text { Nilai } \mathrm{pH} \text { berdasarkan } \\
\text { JIS K } 6833-1980\end{array}$ \\
\hline $\operatorname{Tanin}^{\star}$ & 4,56 & 7 & 104,63 & \multirow{16}{*}{$7-13$} \\
\hline $\mathrm{H} .80$ & 6,15 & 7 & 8,96 & \\
\hline $\mathrm{H} .70$ & 6,33 & 7 & 11.49 & \\
\hline $\mathrm{H} .60$ & 6,45 & 7 & 9,7 & \\
\hline $\mathrm{H} .50$ & 6,60 & 7 & 10,15 & \\
\hline H.40 & 6.85 & 7 & 9,55 & \\
\hline $\mathrm{H} . \mathrm{O}$ & 6,86 & 7 & 5,22 & \\
\hline E.80 & 6,15 & 7 & 8,96 & \\
\hline E.70 & 5,98 & 7 & 5,67 & \\
\hline E.60 & 6,24 & 7 & 5,37 & \\
\hline E.50 & 6,31 & 7 & 8,36 & \\
\hline E. 40 & 6,17 & 7 & 10,15 & \\
\hline E.0 & 6,16 & 7 & 20,15 & \\
\hline D.80 & 6,00 & 7 & 8,96 & \\
\hline D70 & 6,08 & 7 & 10.3 & \\
\hline D. 60 & 6,15 & 7 & 7.91 & \\
\hline
\end{tabular}

Keterangan: - Lanutan tannin $1 \%$

Nilai $\mathrm{pH}$ tertinggi untuk hexamethylene tetramin terjadi pada H.O yaitu 6,86 dan terendah pada H.80. Untuk Ethylene glycol, nilai $\mathrm{pH}$ tertinggi pada E.50 yaitu 6,31 dan terendah pada E.70 yaitu 5,98. Sedangkan nilai $\mathrm{pH}$ untuk dimethylolurea yang terendah pada D. 80 yaitu 6,00 dan tertinggi pada D. 60 yaitu 6,15 . Hal ini menunjukkan bahwa semakin banyak hexamethylene tetramine dan dimethylolurea ditambahkan akan meningkatkan nilai $\mathrm{pH}$ pada perekat tersebut. Sedangkan pada ethylene glycol semakin banyak ditambahkan, nilai pHnya bervariasi tidak berpengaruh.

Nilai $\mathrm{pH}$ dari perlakuan diatas tidak memenuhi syarat standar JIS $\mathrm{K}$ 6833-1980 yang ditetapkan yaitu $7-13$ karena adanya penambahan hexamethyelene, ethylene glycol dan dimethylol urea yang sifatnya asam sehingga mengakibatkan campuran perekat bersifat asam. $\mathrm{Hal}$ ini dinyatakan oleh Kollmann et al. 1975 bahwa derajat keasaman $(\mathrm{pH})$ yang rendah akan menyebabkan kayu rusak, serat kayu dikedua permukaan kayu yang direkat pada kondisi tertentu dapat dipengaruhi sehingga ikatan pada kayu lepas. Sedangkan derajat keasaman $(\mathrm{pH})$ tinggi mempunyai dua fungsi yaitu untuk membersihkan permukaan kayu yang akan direkat dengan cara melarutkan kontaminan yang ada dan untuk mengembangkan zat kayu serta membuka struktur dinding sel sehingga memperbaiki penetrasi dari perekat.

Kapasitas buffer adalah jumlah asam atau basa yang dapat diberikan terhadap larutan buffer tanpa mengubah nilai pHnya. Dalam penelitian ini kapasitas buffer dinyatakan sebagai jumlah $\mathrm{NaOH}$ (mmol) yang digunakan hingga $\mathrm{pH}$ larutan mencapai 7,00 . Nilai kapasitas buffer dalam penelitian ini yang tertinggi pada tannin yaitu 104,63 mmol $\mathrm{NaOH} / 100 \mathrm{gr}$ serat, dengan nilai $\mathrm{pH}$ tannin 4,56 . Sedangkan nilai kapasitas buffer terendah pada $\mathrm{H} . \mathrm{O}$ yaitu 5,22 $\mathrm{mmol} \mathrm{NaOH} / 100 \mathrm{gr}$ serat, dengan nilai $\mathrm{pH}$ 6,86. Hal ini dijelaskan bahwa semakin rendah nilai pHnya maka kapasitas buffer semakin tinggi. $\mathrm{Hal}$ ini disebabkan karena semakin rendah 
nilai $\mathrm{pH}$ tanin maka semakin jauh dari $\mathrm{pH} 7$ (pH sasaran), dan jumlah larutan buffer yang digunakan semakin banyak sehingga nilai kapasitas buffer pun semakin tinggi. Hal ini sesuai dengan hasil penelitian Okum, 1999 dan Rosamah, 2003.

Semakin rendah $\mathrm{pH}$ yang digunakan akan mengakibatkan rusaknya tanin, demikian juga semakin tinggi $\mathrm{pH}$ yang digunakan akan menyebabkan menurunnya reaktifitas tanin. Menurut Achmadi dan Aryati, 1993 bahwa pH tinggi akan menyebabkan terjadinya penataulangan struktur tanin yang akan menurunkan reaktifitasnya. Sedangkan semakin rendah $\mathrm{pH}$ tanin digunakan akan merusak ekstrak tanin karena adanya sifat fenolik yang akan mempengaruhi efektifitas ekstraksi.

\section{KESIMPULAN}

Berdasarkan hasil analisa fisikokimia tanin sebagai bahan perekat maka dapat disimpulkan bahwa ekstrak (tanin) yang dihasilkan memiliki reaktivitas terhadap formaldehida sebesar $96 \%$, reaktivitas terhadap hexamethylene tetramine sebesar $46,18 \%$, reaktivitas terhadap ethylene glycol sebesar $3,07 \%$ dan reaktivitasnya terhadap dimethylolurea $183,59 \%$. Sedangkan nilai kadar polifenol reaktif berdasarkan UV metode pada reaksi tanin dengan formaldehida sebesar $97,65 \%$, tanin dengan hexamethylene tetramine sebesar $46 \%$, tanin dengan ethylene giycol sebesar $2 \%$, dan tanin dengan dimethylolurea sebesar $56,26 \%$.

Waktu gelatinasi yang memenuhi syarat JIS K 6833-1980 adalah perlakuan untuk hexamethylenen tetramine yaitu : variabel II, III, untuk ethylene glycol yaitu variabel $\mathrm{VI}$ yaitu $>35$ menit.

Nilai viskositas yang diperoleh yang memenuhi syarat yang ditetapkan oleh JIS K 6833-1980 adalah perlakuan dengan hexamethylenen tetramine yaitu pada variabel II. III, dan IV, sedangkan untuk ethylene glycol yaitu variabel II s.d variabel VI dengan nilai viskositas $10-13$ dpa.s.

\section{Ucapan Terima Kasih}

Pada kesempatan ini, kami mengucapkan terima kasih kepada Bapak Kepala Balai dalam penyediaan dana untuk penelitian ini, Paluphy Eka Yustini, dan semua pihak yang telah membantu pelaksanaan penelitian baik dalam perlakuan, menganalisa hingga tersusunnya laporan ini.

\section{DAFTAR PUSTAKA}

Anonim, 2006. Data Lapangan di PT Sumalindo Lestari Jaya, Desa Senoni. Kabupaten Kutai Kartanegara.

Achmadi, S., dan Aryetti. 1993. Keragaan Tanin Acacia Mangium Dibandingkan Tanin Mimosa Sebagai Perekat Kayu Lapis, Proyek Peningkatan Penelitian Dan Pengabdian Masyarakat. Institut Pertanian Bogor. Bogor. Unpublished.

Kollmann, F.F.P., E.W. Kuenzi dan A.J. Stamm. 1975.Principles of Wood Science and Technology. Vol. II. Springer-Verlag, Berlin, Heidelberg, Newyork.

Okum, J. 1999. Entwicklung von umweltfreundlichen, reaktiven Bindemittelsystemen aus Reststoffen der Holznutzung (technische Lignine, Rinde) für die Herstellung von emissionsarmen Span- und Faserplatten. Dissertation, Universität Göttingen. Tectum Verlag, Marburg

Parastuti, N., 2002. Analisa Kandungan Zat Ekstraktif dan Abu Kulit Kayu Akasia Mangium (Acacia Mangium Willd) Berdasarkan Kelas Diameter. Skripsi Sarjana Fakultas Kehutanan Universitas Mulawarman Samarinda.

Pizzi, A. 1983. Tanin Based Wood Adhesive. In A. Pizzi Ed. Wood Adhesive : Chemistry and 
Technology. Marcel Dekker, Inc. New York.

Rosamah, E. 1997. The utilization of Tanin from Bark of Acacia mangium Willd. As Adhesive Constituent. Thesis to Obtain The Master of Science Degree in Tropical Forestry at The Faculty of Forestry and Ecology Gerog August- University Gottingen. Unpublished.

Rosamah, E. 2003. Einige Aspekte der Tanninverleimung. Cuvillier Verlag Göttingen. ISBN 3-86537-255-4

Ruhedi, S., Koroh D. S., Syahmani F., Yanti H., Nurhaida, Saad S., Sucipto T. 2007. Analisis Perekatan Kayu. Institut Peranian Bogor. Bogor.

Rowell, R.M. 2005. Handbook of Wood Chemistry and Wood Composites. CRC Press. New York.
Subiyakto, 2008. Memanfaatkan Akasia Sebagai Perekat, Laboratorium Biokomposit UPT Balai Litbang Biomaterial-LIPI, Cibinong, Bogor.

Suhendry. 2006. Analisa Sifat-Sifat Fisika Dan Kimia Tanin dan Tiga Jenis Bakau Yang Berasal Dari Daerah Balikpapan. Fakultas Kehutanan Universitas Mulawarman. Samarinda.

Sujanto.1995. Evaluasi Tanin Mangium, Mimosa dan Quebracho Sebagai Campuran Perekat Kayu Lapis. Thesis Sarjana Jurusan Kimia Fakultas Matematika dan IPA. IPB. Bogor. Unpublished.

Sutigno, P. 1988. Perekat dan Perekatan. Puslitbanghut. Depertemen Kehutanan. Bogor.

Yazaki, Y. Morita and P.J. Collins. 1998. Potential use of Acacia Mangium Bark form Proceding The Fourt Pacific. Proceeding the Fourth Pacific Rim Bio - based Composite Symposium. Bogor. 